\title{
Probiotic, antibiotic and combinations in Nile tilapia juveniles culture
}

\author{
ANDRE L. FERREIRA ${ }^{1}$, MATHEUS P.S. AMORIM ${ }^{1}$, EMILENE R. SOUZA ${ }^{1}$, MARIANNE \\ SCHORER $^{1}$, GUSTAVO H.F. CASTRO ${ }^{2}$ and MARCELO M. PEDREIRA ${ }^{1}$
}

\begin{abstract}
${ }^{1}$ Laboratório de Aquicultura e Ecologia Aquática, Departamento de Zootecnia, Universidade Federal dos Vales do Jequitinhonha e Mucuri, Rodovia MGT 367, Km 583, Alto da Jacuba, 5000, 30100-000 Diamantina, MG, Brazil ${ }^{2}$ Laboratório de Nutrição Animal, Departamento de Zootecnia, Universidade Federal dos Vales do Jequitinhonha e Mucuri, Rodovia MGT 367, Km 583, Alto da Jacuba, 5000, 30100-000 Diamantina, MG, Brazil
\end{abstract}

Manuscript received on February 19, 2018; accepted for publication on July 6, 2019

\begin{abstract}
How to cite: FERREIRA LA, AMORIN MPS, SOUZA ER, SCHORER M, CASTRO GHF AND PEDREIRA MM. 2019. Probiotic, antibiotic and combinations in Nile tilapia juveniles culture. An Bras Acad Cienc 91: e20180169. DOI 10.1590/0001-376201920180169.
\end{abstract}

\begin{abstract}
This study aimed to evaluate the effect of the commercial probiotic (Saccharomyces cerevisiae), antibiotic (florfenicol), and its combination for Nile tilapia culture. The experiment was arranged in a completely randomized design with five replications, and five treatments diets: Control: water and diet without additives; YD: yeast in the diet $\left(1 \mathrm{~g} \mathrm{Kg}^{-1}\right)$; AW: antibiotic in the water $\left(0.002 \mathrm{~g} \mathrm{~L}^{-1}\right)$; AWYD: antibiotic in the water, and yeast in the diet $\left(0.002 \mathrm{~g} \mathrm{~L}^{-1}\right.$ and $\left.1 \mathrm{~g} \mathrm{Kg}^{-1}\right)$; and AD: antibiotic in the diet $\left(0.01 \mathrm{~g} \mathrm{~kg}^{-1}\right)$. The growth parameters as total and standard length, weight, weight gain, biomass, Fulton's condition factor, specific growth rate and plasma cortisol of tilapia did not show the difference between the treatments. The survival rates and food conversion rate of fish were greater in treatment with florfenicol included in the diet. The commercial probiotic did not improve growth or survival. The administration of the antibiotic florfenicol in the water needs more studies. The inclusion of the antibiotic in the diet promotes growth and survival in Nile tilapia juvenile.
\end{abstract}

Key words: animal welfare, florfenicol, yeast, prebiotic and probiotic, growth promoter.

\section{INTRODUCTION}

Several classes of antibiotics are commonly used in aquaculture; Among it, the most used are oxytetracycline and florfenicol due to their high potency against bacterial diseases. These antibiotics were suitable for aquaculture since after a withdrawal period of 15 days its residues in Oreochromis niloticus muscle were within the permissible limit of Commission Regulation, EU

Correspondence to: Andre Lima Ferreira

E-mail: andrelimazootecnista@gmail.com ORCid: https://orcid.org/0000-0001-6947-4675
Commission (2010) and besides this advantage antibiotics provide better performance (Reda et al. 2013).

With the health and environmental concerns, the use of chemotherapeutic agents has been restricted in many countries over recent years. This restriction has resulted in a demand for alternative strategies to improve aquatic production and enhance disease resistance. Among these options, probiotics, live micro-organisms that confer a health benefit to the host by providing both a nutritional benefit and protection against pathogens, represent an important option for the management of diseases and their use may replace some of the therapeutic 
chemicals commonly used in aquaculture (PérezSánchez et al. 2014).

Tilapia is an omnivorous species that intestines and gonads, rearing water and sediments or even commercial products, can be sources for acquiring appropriate probiotics. Administration of probiotics varies from direct oral/water routine to feed additives, of which the latter is most commonly used (Van Hai 2015). The yeast is a probiotic that can improve feed utilization and promote growth performance in a cichlid. Furthermore, using probiotics can control pathogens by a variety of mechanisms, therefore, become it's increasingly important in the aquaculture industry (Mohammadi et al. 2015). However, despite some experiments using the commercial baker's yeast Saccharomyces cerevisiae had attained success in the fish culture (Hisano et al. 2007, Abdel-Tawwab et al. 2008) others may not promote improvement.

This study aimed to evaluate the effect of the probiotic commercial live bakers' yeast (S. cerevisiae), antibiotic (florfenicol), and its combination for Nile tilapia culture.

\section{MATERIALS AND METHODS}

The experiment was carried out at the Laboratório de Aquicultura e Ecologia Aquática of the Universidade Federal dos Vales do Jequitinhonha e Mucuri, JK campus, in Diamantina, MG, $18^{\circ} 15^{\prime} \mathrm{S}$; $43^{\circ} 36^{\prime} \mathrm{W} ; 1,400 \mathrm{~m}$ of altitude, during 56 days. The work was conducted following ethical standards and approved by the Ethics Committee on the Use of Animals of the UFVJM, process $n^{\circ}$ 029/2016.

Nile tilapia juveniles (650 males), weight and length around $1.05 \pm 0.71 \mathrm{~g}$ and $4.01 \pm 0.40 \mathrm{~cm}$ respectively, were stocked into 25 aquariums (130 L), with constant aeration and natural photoperiod (12 hours of light and 12 hours of darkness) in the density of 0.19 fish $\mathrm{L}^{-1}$ aquarium ${ }^{-1}$.

\section{TREATMENTS}

The experiment was arranged in a completely randomized design with five replications, and five treatments diets: Control: water and diet without additives; YD: yeast in the diet $\left(1 \mathrm{~g} \mathrm{Kg}^{-1}\right)$; $\mathrm{AW}$ : antibiotic in the water $\left(0.002 \mathrm{~g} \mathrm{~L}^{-1}\right)$; AWYD: antibiotic in the water, and yeast in the diet $(0.002$ $\mathrm{g} \mathrm{L}^{-1}$ and $\left.1 \mathrm{~g} \mathrm{Kg}^{-1}\right)$; and AD: antibiotic in the diet $\left(0.01 \mathrm{~g} \mathrm{~kg}^{-1}\right)$. The animals were properly acclimated in their experimental units for seven days.

The yeast was manually mixed in the commercial feed and subsequently fixed by soybean oil $\left(1 \mathrm{~mL} \mathrm{~kg}^{-1}\right)$ on top. The same methodology was set to include $0.01 \mathrm{~g} \mathrm{~kg}^{-1}$ of antibiotic florfenicol in the feed, whilst the concentration in the water was $0.002 \mathrm{~g} \mathrm{~L}^{-1}$ was included in all the experimental diets.

\section{PROTOCOL}

The diets were offered ad libitum three times a day $(8,12,16 \mathrm{~h})$, and weighed for the calculus of consumption and apparent feed conversion.

The calculated composition of the extruded commercial feed (1.5 mm of diameter) per $\mathrm{kg}$ of feed was: humidity (max.) $100 \mathrm{~g}$, crude protein (min.) $400 \mathrm{~g}$, lipid analysis (min.) $80 \mathrm{~g}$, crude fiber (max.) $30 \mathrm{~g}$, mineral matter (max.) $160 \mathrm{~g}$, calcium (min.) $15 \mathrm{~g}$, calcium (max.) $30 \mathrm{~g}$, phosphorus (min.) $10 \mathrm{~g}$, sodium (min.) $185 \mathrm{mg}$, lysine (min.) $22 \mathrm{~g}$, methionine (min.) $9.400 \mathrm{mg}$, vitamin A (min.) 18.400 UI, vitamin D3 (min.) 5,000 IU, vitamin E (min.) $400 \mathrm{IU}$ (min.). vitamin K3 (min.) $34.5 \mathrm{mg}$, vitamin C (min.) $1500 \mathrm{mg}$, thiamine (B1) (min.) $36.8 \mathrm{mg}$, riboflavin (B2) (min.) $36.8 \mathrm{mg}$, pyridoxine (min.) $36.8 \mathrm{mg}$, vitamin B12 (min.) $36.8 \mathrm{mg}$, folic acid (min.) $11.5 \mathrm{mg}$, biotin (min.) $0.12 \mathrm{mg}$, niacin (min.) $195.5 \mathrm{mg}$, calcium pantothenate (min.) 92 mg, copper (min.) $19.5 \mathrm{mg}$, manganese (min.) 58 $\mathrm{mg}$, selenium (min.) $0.95 \mathrm{mg}$, zinc (min.) $192 \mathrm{mg}$ and iron (min.) $146 \mathrm{mg}$. 
To remove the waste and the amount of organic matter, twice a week, the aquarium was siphoned and $40 \%$ of the volume was renewed. Weekly the physical parameters of water (temperature, $\mathrm{pH}$, dissolved oxygen and electrical conductivity) were measured through the multi-parameter probe (Horiba W-22XDD). Also, the ammonia, nitrite, and nitrate were analyzed according to the methodology described in APHA (2012).

At the end of the experimental period, fishes were weighed with a precision analytical balance $(0.01 \mathrm{~g})$ and then measured, the total and standard length with a digital caliper $(0.01 \mathrm{~mm})$ after being anesthetized with eugenol $75 \mathrm{mg} \mathrm{L}$, according to a methodology described by Vidal et al. (2008). Also were calculated the biomass (sum of the weight of all fish in the aquarium), the survival, and Fulton's condition factor (K) (weight x standard length $\left.{ }^{-3}\right) * 100$.

At the end of the experimental period, 40 minutes after the last biometry, all fishes were submitted to acute stress, where they were exposed to the air for 12 minutes and then relocated in their experimental units. After acute stress, 24 hours post-stress, the survival rate and the efficiency of the additives was evaluated.

Following the stress, fish of each treatment was captured and then around $200 \mu \mathrm{L}$ of blood from the caudal vein was collected to measure the plasma cortisol level. The blood was collected with a syringe, bathed in anticoagulant (EDTA $3 \%$ ), of the ventral region of the spine. The blood was conditioned in Eppendorf tubes (1.5 $\mathrm{mL}$ ), refrigerated at $12^{\circ} \mathrm{C}$ and then centrifuged (Centrifuge 5415R) at $3000 \mathrm{rpm}$ for fifteen minutes to collect the supernatant plasma with a micropipette. The plasma was refrigerated, in duplicates, at $-80^{\circ} \mathrm{C}$ for further cortisol analysis, which was determined by the ELISA kit (enzymelinked immunosorbent kit - cortisol test MonobindInc () ). Intra and interspecific tests were performed to validate the plasma cortisol kits in tilapia juveniles.

At the end of the experimental period, fish from both experiments were euthanized with benzocaine hydrochloride (CONCEA 2013) for the body chemical composition analyzes. The following analyses, dry matter, crude protein, lipid analyze, and mineral matter (AOAC 2016) were performed in the Laboratory of Animal Nutrition - UFVJM.

\section{STATISTICAL ANALYSIS}

All data were submitted to ANOVA, followed by Tukey test (0.05). The data for survival were transformed into arcsin for statistical analysis, but are presented in percentages. The analyses were performed using the statistical program SIGMA STAT 3.5.

\section{RESULTS}

The physical-chemical parameters of water, temperature, $\mathrm{pH}$, electrical conductivity, ammonia, and nitrate did not show statistic difference $(\mathrm{p}>0.05)$ between the treatments. However, the dissolved oxygen and nitrite has a statistical difference $(\mathrm{p}<0.05)$ (Table I).

The total and standard length, weight, weight gain, biomass, Fulton's condition factor, and specific growth rate of tilapia did not have difference $(p>0.05)$ between the treatments (Table II).

Feed conversion was better in the treatment with florfenicol in the diet than in the control group. Likewise, the consumption was different between the treatments, where the juveniles in the treatment with florfenicol in the diet shown higher $(\mathrm{p}<0.05)$ consumption when compared to the control.

During the experimental period, the survival rate was higher $(p<0.05)$ from the treatment with florfenicol in the diet, followed by the treatments with yeast in the diet and the control group, then the treatment with florfenicol in water and finally by the florfenicol in the water and yeast in the diet. 
TABLE I

Mean values and standard deviation of the physical-chemical parameters of the water in the culture of Nile tilapia juvenile supplemented with yeast (Saccharomyces cerevisiae), antibiotic (florfenicol) and its consortium, during 56 days.

\begin{tabular}{ccccccc}
\hline Parameters & Control & YD & AW & AWYD & AD & CV (\%) \\
\hline Temperature $\left({ }^{\circ} \mathrm{C}\right)$ & $21.86 \pm 1.29 \mathrm{a}$ & $21.80 \pm 1.21 \mathrm{a}$ & $21.82 \pm 1.07 \mathrm{a}$ & $21.98 \pm 1.13 \mathrm{a}$ & $21.85 \pm 1.16 \mathrm{a}$ & 0.47 \\
$\mathrm{pH}$ & $7.77 \pm 0.99 \mathrm{a}$ & $7.95 \pm 0.95 \mathrm{a}$ & $7.85 \pm 1.00 \mathrm{a}$ & $7.94 \pm 0.90 \mathrm{a}$ & $7.82 \pm 0.90 \mathrm{a}$ & 1.88 \\
& $0.03 \pm 0.01 \mathrm{a}$ & $0.02 \pm 0.01 \mathrm{a}$ & $0.03 \pm 0.01 \mathrm{a}$ & $0.03 \pm 0.02 \mathrm{a}$ & $0.03 \pm 0.02 \mathrm{a}$ & 27.94 \\
Electrical conductivity & & & & & \\
$\left(\mathrm{mS} \mathrm{cm}^{-1}\right)$ & $7.66 \pm 3.09 \mathrm{a}$ & $6.97 \pm 0.96 \mathrm{ab}$ & $6.72 \pm 0.86 \mathrm{ab}$ & $6.65 \pm 0.85 \mathrm{~b}$ & $6.81 \pm 0.86 \mathrm{ab}$ & 7.61 \\
Dissolved oxygen $\left(\mathrm{mg} \mathrm{L}^{-1}\right)$ & $0.09 \pm 0.02 \mathrm{a}$ & $0.09 \pm 0.02 \mathrm{a}$ & $0.11 \pm 0.04 \mathrm{a}$ & $0.11 \pm 0.03 \mathrm{a}$ & $0.13 \pm 0.06 \mathrm{a}$ & 35.85 \\
Ammonia $\left(\mathrm{mg} \mathrm{L}^{-1}\right)$ & $0.01 \pm 0.02 \mathrm{~b}$ & $0.04 \pm 0.01 \mathrm{ab}$ & $0.08 \pm 0.04 \mathrm{a}$ & $0.02 \pm 0.02 \mathrm{ab}$ & $0.01 \pm 0.02 \mathrm{~b}$ & 70.64 \\
Nitrite $\left(\mathrm{mg} \mathrm{L}^{-1}\right)$ & $0.46 \pm 0.57 \mathrm{a}$ & $1.14 \pm 0.32 \mathrm{a}$ & $0.75 \pm 0.60 \mathrm{a}$ & $0.37 \pm 0.64 \mathrm{a}$ & $0.37 \pm 0.64 \mathrm{a}$ & 91.77 \\
Nitrate $\left(\mathrm{mg} \mathrm{L}^{-1}\right)$ & &
\end{tabular}

Means followed by different letters in the same row were significantly different according to Tukey's test ( $\mathrm{p}<0.05)$. Control: water and diet without additives; YD: yeast in the diet $\left(1 \mathrm{~g} \mathrm{Kg}^{-1}\right)$; AW: antibiotic in the water $\left(0.002 \mathrm{~g} \mathrm{~L}^{-1}\right)$; AWYD: antibiotic in the water, and yeast in the diet $\left(0.002 \mathrm{~g} \mathrm{~L}^{-1}\right.$ and $\left.1 \mathrm{~g} \mathrm{Kg}^{-1}\right)$; and AD: antibiotic in the diet $\left(0.01 \mathrm{~g} \mathrm{~kg}^{-1}\right)$.

The survival of Nile tilapia juvenile was $100 \%$ for all treatments after the stress by air exposure.

For the plasmatic cortisol, no differences $(p>0.05)$ were observed between the treatments after air exposure, and values oscillated among 2.18 to $2.21 \mu \mathrm{g} \mathrm{dL}^{-1}$.

The body chemical composition of Nile tilapia juveniles has it dry matter greater $(p<0.05)$ while reared with florfenicol in the water and yeast in the diet when compared to the control. However, it is similar to the treatment with yeast in the diet, with florfenicol in the water, and florfenicol in the diet (Table III).

The lipid analysis of the body chemical composition of the treatment with florfenicol in the water and yeast in the diet was higher $(\mathrm{p}<0.05)$ when compared to treatments with florfenicol in the diet, yeast in the diet, and control. However, it is similar to the treatment with florfenicol in the water.

The crude protein and mineral matter did not have a statistical difference $(p>0.05)$ between the treatments.

\section{DISCUSSION}

The following physical-chemical parameters of the water, $\mathrm{pH}$, electrical conductivity, dissolved oxygen, ammonia, nitrite, and nitrate, were suitable for the cultivation of Nile tilapia, however, the temperature was below the range for maximum performance of the species (Mercante et al. 2011).

The weight, weight gain, and biomass did not differ between the treatments. It may be occurred due to the established microbiota being resistant to other microorganisms (Gatesoupe 1999) since probiotic by competitive exclusion may or may not settle in the sites in the digestive tract of the organism (Loh 2017). Other authors when supplementing yeast in the diets of tilapias reports no difference in growth and weight gain (He et al. 2009, Schwarz et al. 2016). However, the $S$. cerevisiae in the diet improved the final weight, weight gain and biomass in Nile tilapia (Hisano et al. 2007, Abdel-Tawwab et al. 2008), also showed improvement when was introduced the lyophilized form (Hisano et al. 2007), and to cichlid fingerlings of Amatitlania nigrofasciata when administered $2 \%$ in the diet (Mohammadi et al. 2015). Adel et al. (2017) described that yeast probiotics have great promise, yet they received little attention in fish. For the authors, all growth performance parameters were significantly improved following probiotic administration due to digestive physiology had been affected by in-feed probiotics through the improvement of intestinal enzyme activities, also, 
TABLE II

Mean values and standard deviation of performance parameters in Nile tilapia juvenile supplemented with yeast (Saccharomyces cerevisiae), antibiotic (florfenicol) and its consortium, during 56 days.

\begin{tabular}{ccccccc}
\hline Parameters & Control & YD & AW & AWYD & AD & CV (\%) \\
\hline Total length $(\mathrm{cm})$ & $7.95 \pm 1.01 \mathrm{a}$ & $7.49 \pm 1.20 \mathrm{a}$ & $7.74 \pm 1.20 \mathrm{a}$ & $7.84 \pm 1.47 \mathrm{a}$ & $7.75 \pm 1.18 \mathrm{a}$ & 6.21 \\
Standard length $(\mathrm{cm})$ & $6.35 \pm 0.81 \mathrm{a}$ & $6.11 \pm 0.98 \mathrm{a}$ & $6.16 \pm 1.04 \mathrm{a}$ & $6.29 \pm 1.22 \mathrm{a}$ & $6.19 \pm 0.99 \mathrm{a}$ & 6.10 \\
Weight $(\mathrm{g})$ & $8.97 \pm 3.29 \mathrm{a}$ & $7.70 \pm 3.53 \mathrm{a}$ & $8.09 \pm 3.82 \mathrm{a}$ & $9.09 \pm 5.28 \mathrm{a}$ & $8.49 \pm 4.20 \mathrm{a}$ & 19.19 \\
Weight gain $(\mathrm{g})$ & $7.90 \pm 1.78 \mathrm{a}$ & $6.72 \pm 1.92 \mathrm{a}$ & $7.13 \pm 2.46 \mathrm{a}$ & $7.89 \pm 3.26 \mathrm{a}$ & $7.44 \pm 2.26 \mathrm{a}$ & 21.42 \\
Biomass $(\mathrm{g})$ & $89.76 \mathrm{a} \pm 3.29$ & $77.12 \mathrm{a} \pm 3.53$ & $80.96 \mathrm{a} \pm 3.82$ & $91.01 \mathrm{a} \pm 5.28$ & $84.97 \mathrm{a} \pm 4.20$ & 19.19 \\
Feed conversion $\left.(\mathrm{g} \mathrm{g})^{-1}\right)$ & $1.69 \pm 0.69 \mathrm{~b}$ & $1.99 \pm 0.87 \mathrm{e}$ & $1.87 \pm 0.45 \mathrm{~d}$ & $1.78 \pm 0.56 \mathrm{c}$ & $1.64 \pm 0.32 \mathrm{a}$ & 0.38 \\
Consumption (g) & $40.77 \pm 2.62 \mathrm{e}$ & $44.33 \pm 3.32 \mathrm{~d}$ & $41.16 \pm 2.83 \mathrm{c}$ & $46.00 \pm 3.34 \mathrm{~b}$ & $57.12 \pm 3.84 \mathrm{a}$ & 7.89 \\
Fulton's condition (K) & $3.44 \pm 2.05 \mathrm{a}$ & $3.29 \pm 2.25 \mathrm{a}$ & $3.41 \pm 2.43 \mathrm{a}$ & $3.62 \pm 3.25 \mathrm{a}$ & $3.39 \pm 2.59 \mathrm{a}$ & 6.58 \\
Specific growth rate (\%) & $7.05 \pm 1.79 \mathrm{a}$ & $5.94 \pm 1.90 \mathrm{a}$ & $6.38 \pm 2.45 \mathrm{a}$ & $6.93 \pm 3.22 \mathrm{a}$ & $6.61 \pm 2.24 \mathrm{a}$ & 23.99 \\
Survival (\%) & $87.15 \pm 1.34 \mathrm{~b}$ & $87.15 \pm 1.34 \mathrm{~b}$ & $85.55 \pm 1.81 \mathrm{c}$ & $83.15 \pm 1.78 \mathrm{~d}$ & $94.35 \pm 0.44 \mathrm{a}$ & 0.08 \\
Post-stress survival (\%) & $100 \pm 0.00$ & $100 \pm 0.00$ & $100 \pm 0.00$ & $100 \pm 0.00$ & $100 \pm 0.00$ & - \\
\hline
\end{tabular}

Means followed by different letters in the same row were significantly different according to Tukey's test ( $<<0.05)$. Control: water and diet without additives; YD: yeast in the diet $\left(1 \mathrm{~g} \mathrm{Kg}^{-1}\right)$; $\mathrm{AW}$ : antibiotic in the water $\left(0.002 \mathrm{~g} \mathrm{~L}^{-1}\right)$; AWYD: antibiotic in the water, and yeast in the diet $\left(0.002 \mathrm{~g} \mathrm{~L}^{-1}\right.$ and $\left.1 \mathrm{~g} \mathrm{Kg}^{-1}\right)$; and $\mathrm{AD}$ : antibiotic in the diet $\left(0.01 \mathrm{~g} \mathrm{~kg}^{-1}\right)$.

* The statistical analyze was not performed.

the inhibitory potential of skin mucus against fish pathogens was significantly enhanced. However, the experiment with trout and the yeast-based commercial probiotic composed of $S$. cerevisiae and Saccharomyces elipsoedas, and under other environmental conditions.

The standard and total length did not differ between treatments, which may be related to beneficial microbiota pre-existent in the aquariums in this study, as described by Gatesoupe (1999) and Merrifiel et al. (2010). Experiments have demonstrated that several probiotics sources can be suitable for tilapia (Van Hai 2015). The results corroborated to Ferreira et al. (2015) who observed that when supplementing Nile tilapia larvae with S. cerevisiae strains, after a sanitary challenge, there were no effects on these parameters between the treatments. Schwarz et al. (2016) also did not observe differences in tilapia length after the use of S. cerevisiae.

Fulton's condition fact is attributed to fish welfare (Gupta and Gupta 2006). For this study, there is no difference between the treatments.
During the experimental period, the $\mathrm{K}$ ranged from 3.29 to $3.62 \pm 0.33$. Pedreira et al. (2016) reported a variation range of $\mathrm{K}$ in tilapia between 2.75 and $3.09 \pm 0.32$. Wild et al. (2014) when testing B. cereus, B. subtillis and its consortium in Nile tilapia reported values ranging from 1.83 to 2.04 , lower than those observed in the present study. The results suggest that the environment was favorable to the tilapia culture.

The specific growth rate did not vary between treatments and ranged from 5.94 to 7.05\%. However, Marengoni et al. (2010) when supplementing B. subtilis, Bacillus lincheniformis and Bacillus pumilus in red tilapia, observed an improvement in the specific growth rate for tilapia.

In this experiment, the tilapias presented better-feed conversion and higher feed intake when supplemented with florfenicol in the diet, corroborating with Reda et al. (2013) who reported that the florfenicol improved the alimentary efficiency of tilapia juveniles.

The feed conversion ranged from 1.64 to 1.99 $\mathrm{g} \mathrm{g}^{-1}$ being the best results found with an antibiotic 
TABLE III

Mean values and standard deviation of the body chemical composition analyses of the Nile tilapia juveniles.

\begin{tabular}{ccccccc}
\hline Composition $\left(\mathbf{g ~ K g}^{-1}\right)$ & Control & YD & AW & AWYD & AD & $\begin{array}{c}\text { CV } \\
(\%)\end{array}$ \\
\hline Dry matter & $25.45 \pm 0.03 \mathrm{~b}$ & $25.84 \pm 0.17 \mathrm{ab}$ & $26.42 \pm 0.02 \mathrm{ab}$ & $26.52 \pm 0.42 \mathrm{a}$ & $26.14 \pm 0.31 \mathrm{ab}$ & 0.96 \\
Crude protein & $13.66 \pm 2.86 \mathrm{a}$ & $13.90 \pm 2.95 \mathrm{a}$ & $14.18 \pm 0.35 \mathrm{a}$ & $14.75 \pm 2.24 \mathrm{a}$ & $13.92 \pm 0.20 \mathrm{a}$ & 4.56 \\
Lipid analysis & $6.02 \pm 0.56 \mathrm{c}$ & $6.35 \pm 0.75 \mathrm{bc}$ & $6.73 \pm 0.30 \mathrm{ab}$ & $6.98 \pm 0.30 \mathrm{a}$ & $6.42 \pm 0.60 \mathrm{~b}$ & 1.49 \\
Mineral matter & $3.60 \pm 0.14 \mathrm{a}$ & $3.63 \pm 0.40 \mathrm{a}$ & $3.63 \pm 0.27 \mathrm{a}$ & $3.43 \pm 0.21 \mathrm{a}$ & $3.70 \pm 0.28 \mathrm{a}$ & 3.05 \\
\hline
\end{tabular}

Control: water and diet without additives; YD: yeast in the diet $\left(1 \mathrm{~g} \mathrm{Kg}^{-1}\right)$; AW: antibiotic in the water $\left(0.002 \mathrm{~g} \mathrm{~L}^{-1}\right)$; AWYD: antibiotic in the water, and yeast in the diet $\left(0.002 \mathrm{~g} \mathrm{~L}^{-1}\right.$ and $\left.1 \mathrm{~g} \mathrm{Kg}^{-1}\right)$; and AD: antibiotic in the $\operatorname{diet}\left(0.01 \mathrm{~g} \mathrm{~kg}^{-1}\right)$.

in the diet, which demonstrated a greater efficiency of the antibiotic in the diet as a growth promoter. On the other hand, the best feed conversion observed in the control group, when compared to yeast in the diet, may be explained by the possible presence of a beneficial microbiota in the fish's intestine or the aquariums, that must have been tolerant to the adhesion of the yeast supplemented in this study, as suggested by Gatesoupe (1999) and Merrifield et al. (2010). Additionally, it would explain the results observed for total and standard length, which appears to be ambiguous.

The consumption ranged from 280.68 to 282.27 g, varying among all the treatments. Schwarz et al. (2016) including B. subtilis in the diet of Nile tilapia fingerlings at a suitable environment for rearing the species, observed values of 1.32 to 1.49 $\mathrm{g} \mathrm{g}^{-1}$ for feed conversion and 249.12 to $318.32 \mathrm{~g}$ for consumption. Those results were similar to this study, indicating that the environmental conditions in this experiment are favorable for the cultivation of this species.

The survival was better in the treatment with florfenicol in the diet, which shows that concentration of antibiotic used in this experiment was effective for the maintenance survival suitable for the species (Carraschi et al. 2011, Andrade et al. 2017). According to Carraschi et al. (2011), the antibiotic florfenicol supplied in the diet at the concentration of $10.0 \mathrm{mg} \mathrm{kg}^{-1}$, provided greater survival in pacus (Piaractus mesopotamicus).
However, when fed with yeast $S$. cerevisiae it does not differ from the control group, similar to the results found for final weight, standard and total length observed in this experiment, suggesting a beneficial effect of the pre-existing microbiota.

All fish survived after the air exposure stress. The tilapia has good resistance to low oxygen conditions due to its ability to produce endogenous antioxidant substances that are capable of reducing the oxidative stress and to regulate cellular respiration (Welker et al. 2013). Besides, animals under stress will try to balance its homeostasis to maintain the integrity of their body through the energy that could be used for productive performance and reproduction (Vijayan et al. 1994, Schreck 2010). Species that tolerate extreme conditions of hypoxia, such as Nile tilapia, have developed important physiological adaptations over time, such as the greater affinity between the oxygen molecule and the hemoglobin, a process that allowed those species to adapt to diverse environments (Nilsson and Östlund-Nilsson 2008).

The concentration of plasma cortisol poststress ranged from 2.18 to $2.21 \mathrm{ng} \mathrm{mL}^{-1}$ and did not differ between treatments. The result is within the basal range for fish (Barton et al. 2002), indicating that the fish remained in a good condition of wellbeing, which is reinforced by the other parameters and survival rates observed.

The variations of the body chemical composition may be related to the products used 
to supplement the animals. The same results were observed in broilers fed with the antibiotic, prebiotic, probiotic, where the authors reported a higher protein deposition in the breast of broilers fed the different supplements about the negative treatment with the antibiotic (Brzoska and Stecka 2007). In this experiment, fish have a better performance when the antibiotic was administered, similarly to results observed by Andrade et al. 2017. However, Abdel-Tawwab et al. (2008). observed higher protein deposition in the carcass after the supplementation of $S$. cerevisiae in the diets for Nile tilapia juveniles.

\section{CONCLUSIONS}

The florfenicol included in Nile tilapia diet improves growth and survival, but in the water, this additive was effective and need more study. The probiotic Saccharomyces cerevisiae did not improve Nile tilapia growth.

\section{ACKNOWLEDGMENTS}

We would like to thank all the research partners of the Laboratório de Aquicultura e Ecologia Aquática of the Universidade Federal dos Vales do Jequitinhonha e Mucuri (UFVJM) for all the assistance during the experiment. To the Dr. Paula Adriane Perez Ribeiro and to researcher Leandro Costa Santos both from the Laboratory of Aquaculture of Universidade Federal de Minas Gerais (UFMG) for the donation of Flofernicol used in the research. Also to Dr. Felipe Shindy Aiura and Dr. Sandra Regina Freitas Pinheiro for the valuable considerations for the development of this study. Finally acknowledgments to Coordenação de Aperfeiçoamento de Pessoal de Nível Superior (CAPES), Código de Financiamento 001, Conselho Nacional de Desenvolvimento Científico e Tecnológico (CNPq), Fundação de Amparo à Pesquisa do Estado de Minas Gerais (FAPEMIG) and Banco do Nordeste do Brasil (BNB/FUNDECI
2012/324) for financial support and Universidade Federal dos Vales do Jequitinhonha e Mucuri (UFVJM) and Companhia de Desenvolvimento dos Vales do São Francisco e do Parnaíba (CODEVASF) for the priceless logistical support.

\section{AUTHOR CONTRIBUTIONS}

Andre Lima Ferreira planned and carried out the experiment, developed the laboratory and statistical analysis, took the lead in writing the manuscript. Matheus Phillip Santos Amorim carried out the experiment and assisted in the cortisol analysis. Emilene Rodrigues Souza carried out the experiment and assisted in the body chemical composition analyses. Marianne Schorer carried out the experiment and translated the manuscript (Portuguese to English). Gustavo Henrique de Frias Castro assisted to perform the body chemical composition analyses and contributed to the interpretation of the results. Marcelo Mattos Pedreira conceived the study and was in charge of overall direction and planning.

\section{REFERENCES}

ABDEL-TAWWAB M, ABDEL-RAHMAN AM AND ISMAEL NEM. 2008. Evaluation of commercial live baker's yeast, Saccharomyces cerevisiae as a grow than dimmunity promoter forfry Nile tilapia, Oreochromis niloticus (L.) challenged in situ with Aeromonas hydrophila. Aquaculture 280(1): 185-189.

ADEL M, LAZADO CC, SAFARI R, YEGANEH S AND ZORRIEHZAHRA MJ. 2017. Aqualase ${ }^{\circledR}$, a yeastbased in-feed probiotic, modulates intestinal microbiota, immunity and growth of rainbow trout Oncorhynchus mykiss. Aquac Res 48(4): 1815-1826.

ANDRADE TJV, SOUSA FA AND MORAIS CR. 2017. Avaliação do florfenicol como tratamento preventivo de doenças bacterianas no cultivo de tilápias em sistema superintensivo. Getec 6(13): 13-25.

AOAC - ASSOCIATION OF OFFICIAL ANALYTICAL CHEMISTRY $\mathrm{OIIIFIDOMHMRGVRI \$ S} \mathrm{QDO} \mathrm{UV.2016.} 20^{\text {th }}$

向lled., Arlington: AOAC International, 2610 p.

IIIAPHA - AMERICAN PUBLIC HEALTH ASSOCIATION UIISTANDARD METHODS FOR THE EXAMINATION OF WATER AND WASTEWATER. 2012. $22^{\text {nd }}$ ed., Washington: American Public Health Association, American Water Works Association, Water Environment Federation, $1496 \mathrm{p}$. 
BARTON BA, MORGAN JD AND VIJAYAN MM. 2002. Physiological and condition- related indicators of environmental stress in fish. In: Adams SM (Ed), Biological indicators of ecosystem stress. Bethesda: Am Fish Soc, p. 111-148.

BRZOSKA F AND STECKA K. 2007. Effect of probiotic, prebiotic and acidifier on the body weight of broiler chickens, feed conversion, and carcass and meat composition. Ann Anim Sci 2(7): 279-288.

CARRASCHI SP, CRUZ C, MACHADO NJG, CASTRO MP, BORTOLUZZI NL AND GIRIO ACF. 2011. Efficacy of the florfenicol and of the oxytetracycline in the control in Aeromonas hydrophila in pacu (Piaractus mesopotamicus). Arq Bras Med Vet Zootec 63(3): 579-583.

CONCEA. 2013. Diretrizes da prática de eutanásia do conselho nacional de controle de experimentação animal. Brasília: Ministério da Ciência, Tecnologia e Inovação, 54 p.

EU COMMISSION. 2010. Commission Regulation (EU) No $37 / 2010$ of 22 December 2009 on pharmacologically active substances and their classification regarding maximum residue limits in foodstuffs of animal origin. Official Journal of the European Union, L15.

FERREIRA AHC, BRITO JM, LOPES JB, SANTANA JHA, BATISTA JMM, SILVA BR, SOUZA EM AND AMORIM ILS. 2015. Probiótico na alimentação de pós-larvas de tilápias-do-Nilo submetidas a desafio sanitário. Rev Bras Saúde Prod Anim 16(2): 430-439.

GATESOUPE FJ. 1999. The use of probiotics in aquaculture. Aquaculture 180(1-2): 147-165.

GUPTA SK AND GUPTA PC. 2006. General and applied ichthyology: fish and fisheries New Delhi: S. Chand and Company PVT, $1156 \mathrm{p}$.

HE S, ZHOU Z, LIU Y, SHI P, YAO B, RINGO E AND YOON I. 2009. Effects of dietary Saccharomyces cerevisiae fermentation product (DVAQUA ${ }^{\circledR}$ ) on growth performance, intestinal autochthonous bacterial community and non-specific immunity of hybrid tilapia (Oreochromis niloticus $9 \times 0$. aureus $\bigcirc$ ) cultured in cages. Aquaculture 294(1): 99-107.

HISANO H, NARVÁEZSOLARTE WV, BARROS MM AND PEZZATO LE. 2007. Desempenho produtivo de alevinos de tilápia-do-Nilo alimentados com levedura e derivados. Pesqui agropec bras 42(7): 1035-1042.

LOH JY. 2017. The role of probiotics and their mechanisms of action: an aquaculture perspective. JWAS 18(1): 19-23.

MARENGONI NG, ALBURQUERQUE DM, MOTA FLS, PASSOS NOP, SILVA NAA, SILVA AIM AND OGAWA M. 2010. Performance and sexual proportion in red tilapia under inclusion of probiotic in mesohaline water. Arch Zootec 59(227): 403-414.

MERCANTE CTJ, CARMO CF, RODRIGUES CJ, OSTI JAS, MAINARDES-PINTO CS, VAZ-DOS-SANTOS AM, TUCCI A AND DI-GERANO AC. 2011. Limnologia de viveiro de criação de tilápias do Nilo: avaliação diurna visando boas práticas de manejo. Bol Inst Pesca 37(1): 73-84.
MERRIFIELD DL, DIMITROGLOU A, FOEY A, DAVIES SJ, BAKER RTM, BOGWALG J, CASTEX M AND RINGO E. 2010. The current status and future focus of probiótico and prebiotic applications for salmonids. Aquaculture 302(1-2): 1-18.

MOHAMMADI F, MOUSAVI SM, AHMADMORADI E, ZAKERI M AND JAHEDI A. 2015. Effects of Saccharomyces cerevisiae on survival rate and growth performance of convict cichlid (Amatitlanianigro fasciata). IJVR 16(1): 59-66.

NILSSON GE AND ÖSTLUND NISSON S. 2008. Does size matter for hypoxia tolerance in fish? Biol Ver Camb Philos Soc 83(2): 173-189.

PEDREIRA MM, SCHORER M, OLIVEIRA IF AND TESSITORE AJ. 2016. Cultivo de duas linhagens de tilápias nilóticas sob diferentes densidades de estocagem em tanques-rede Ciênc Anim Bras 14(n.cont.): 37-45.

PÉREZ-SÁNCHEZ T, RUIZ-ZARZUELA I, DE BLAS I AND BALCÁZAR JL. 2014. Probiotics in aquaculture: a current assessment. Rev Aquacult 6(3): 133-146.

REDA MR, IBRAHIM RE, AHMED ENG AND EL-BOUHY ZM. 2013. Effect of oxytetracycline and florfenicol as growth promoter son the health status of cultured Oreochromis niloticus. Egypt J Aquat Res 39(4): 241-248.

SCHRECK CB. 2010. Stress and fish reproduction: the roles of allostasis and hormesis. Gen Comp Endocrinol 165(3): 549-556.

SCHWARZ KK, RAMOS AC, SCHLOTTAG BB, LUZ MNM, ROCHA TAR AND SILVA CH. 2016. Probiótico, prebiótico e simbiótico na nutrição de alevinos de tilápia do Nilo Oreochromis niloticus. Arch Vet Sci 21(2): 43-51.

VAN HAI N. 2015. Research findings from the use of probiotics in tilapia aquaculture: a review. Fish \& Shellfish Immunology 45(2): 592-597.

VIDAL LVO, ALBINATI RCB, ALBINATIL ACL, LIRAAD, ALMEIDA TR AND SANTOS GB. 2008. Eugenol como anestésico para a tilápia-do-Nilo. Pesqui Agropec Brás 43(8): 1069-1074.

VIJAYAN MM, REDDY PK, LEATHERLAND JF AND MOON TW. 1994. The effects of cortisol on hepatocyte metabolism in rainbow trout. A study using the steroid analog RU486. Gen Comp Endocrinol 96(1): 75-84.

WELKER AF, MOREIRA DC, CAMPOS EG AND HERMES-LIMA M. 2013. Role of redox metabolism for adaptation of aquatic animals to drastic changes in oxygen availability. Comp Biochem Physiol A Mol Integr Physiol 165(4): 384-404.

WILD MB, MARENGONI NG, VIVIAN MMPS, TSUTSUMI CY AND MOURA MC. 2014. Probiótico dietético em sistemas de produção de tilápia do Nilo: efeitos sobre o crescimento, balanço de $\mathrm{N}$ e $\mathrm{P}$, retenção de nutrientes e viabilidade econômica. Semin Cienc Agrar 35(1): 477-489. 